\title{
Gender Equality and Gender Difference in Team - Coverage - Lessons From the Ice Hockey Rink
}

\section{EXERCISE IS MEDICINE}

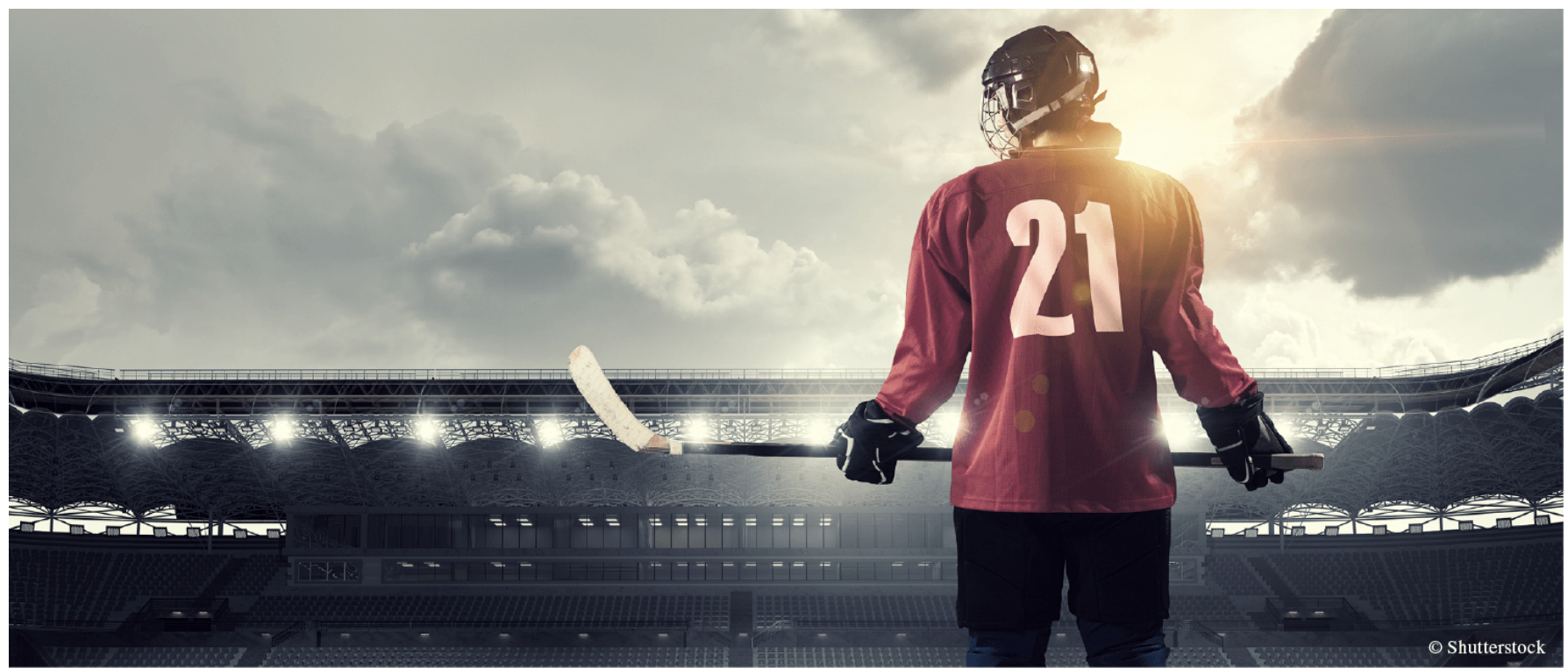

\section{Erat Anna}

Director of Check-up Center Hirslanden, Klinik Hirslanden

\begin{abstract}
Covering all female sports teams poses particular challenges. Since the Title IX established in the U.S. in 1972 ensuring that men and women have equitable participation opportunities, as well as access to scholarships in sport programs, and since UNESCO recognized sports and physical activity as a human right in 1978, the world and the global sports communities have come a long way in pursuing gender equality in sports.

However, gender equality in sports does not mean that gender differences shouldn't be researched or considered while developing training plans and programs, and in the prevention and treatment of disease and injury. Indeed, there is undeniably plenty of scientific evidence that sex and gender differences play a major role when it comes to disease risks and symptoms, injury patterns and frequency, and also in regards to response to treatments. The covering medical professional needs to appreciate these facts and include them into his decision making process.

Based on experience as a team doctor for female athletes on the national team, I propose three levels that
\end{abstract}


must be considered when addressing gender and sex differences in team coverage, namely 1) the psychosocial level, 2) the epidemiological level, and 3) the individual level concerning the female body.

\section{Zusammenfassung}

Die Betreuung von Frauenmannschaften stellt besondere Herausforderungen dar, wie schon der Name «Frauenmannschaft» zeigt. Es wurden grosse Fortschritte erreicht, seit in den USA 1972 der Title IX geschaffen wurde, der sicherstellt, dass Frauen und Männer gleiche Möglichkeiten haben, an Sport und Wettkämpfen teilzunehmen und gleichen Zugang zu Förderprogramm erreichen, und die UNESCO 1978 Sport und körperliche Aktivtät als Menschenrecht definiert hat.

Trotzdem heisst Geschlechtergleichheit nicht, dass Geschlechterunterschiede nicht erforscht und berücksichtigt werden sollen, besonders in der Entwicklung von Trainingsplänen, in der Verletzungsprophylaxe und der Behandlung von Erkrankungen und Unfällen. Im Gegenteil, es gibt eine starke Evidenzlage, dass das Geschlecht einen signifikanten Einfluss auf Verletzungsrisiko und -muster und Behandlungserfolg hat. Der Teamarzt muss diese Fakten wahrnehmen und in seine Entscheidungen mit einfliessen lassen.

Basierend auf der Erfahrung als Teamärztin eines Frauen- Nationalteams schlage ich drei Stufen vor, auf denen Geschlechterunterschiede in der Teambetreuung bedacht werden müssen: 1) der psychosoziale Level, 2) der epidemiologische Level und 3) die individuelle Sportlerin.

\section{Introduction}

I am a great believer in gender equality and therefore human rights in sports, not only due to ethical and moral reasons, but also on grounds of socioeconomic benefit. Indeed, it is well known that girls who play sports are less likely to drop out of school, to reach higher levels of education, they are more likely to take up leadership positions and they suffer fewer health problems. In fact, a joint study by Ernst and Young and ESPNW surveyed 400 women in executive positions and found that 94 percent of C-Suite executives today were former athletes [1]. Furthermore, supporting girls and women in sport leads to stronger women with critical thinking and leadership skills, stronger communities, and significantly contributes to economic growth overall [2].

However, equality in sports does not mean that gender differences shouldn't be researched or considered while developing training plans and programs, and in the prevention and treatment of disease and injury. Men and women are after all different when it comes to disease risks and symptoms, injury patterns and frequency, and even in regards to response to treatments. While advocating equal rights and opportunities, it is hence also crucial to stimulate a discussion and to consider sex and gender differences while working with athletes and taking care of sports teams.

\section{The Psychosocial Level: Sports Psychology, Abuse and Team Building}

Mental disorders are common in competitive sports and they can significantly influence performance, increase the risk of physical injuries and prolong rehabilitation. Sports medicine physicians and staff often encounter psychological issues with patient-athletes, yet the majority of athletes rarely or never get a referral to sport psychologists [3]. In female athletes, structural and financial inequalities such as a lack of 
airtime on television, or being exposed to excessive sexism and discrimination, set the stage for or exacerbate stress and may impact the health of elite female athletes [4]. Furthermore, factors such as the menstrual cycle, pre-menstrual syndrome, pregnancy and post-partum depression clearly need to be addressed in female teams as opposed to men's teams. Therefore, psychiatry needs to play a role in prevention, detection and treatment of mental health disorders of athletes while taking into consideration sex and gender.

Yet, girls and women athletes are still today often discriminated as mentioned before, or unfortunately even abused. Particularly the USA Gymnastics sex abuse scandal and the media attention around sexual harassment in different industries have brought this discrimination to light and underscore the importance of protecting female athletes from complex stress phenomena and molestation [5]. The example of sexual abuse by Lawrence G. Nassar, the former doctor for the American women's gymnastics team who was sentenced to decades in prison after multiple convictions, clearly shows that the abuse and threat do not always derive from external players, but can originate in the team itself and staff members. It is therefore important to cultivate a healthy environment for the team and staff, while protecting the players from crime and providing security while travelling abroad in unsafe regions.

However, not only mental disorders and the prevention of disease play a role in team sports. For optimal performance and wellbeing, team-building and mental resilience are highly critical. The fact that groups can influence outcomes important to both the individual and the group has been recognized for decades. Among these factors, cohesion represents one of the most extensively studied psychological aspects that influence group dynamics and performance. Cohesion can be thought of as the glue that acts to attract and retain members within a groups and influence their behavior as well as performance. The attention given to cohesion among sport psychology researchers is fairly vast, as cohesion has consistently been found to predict team performance, and measures supporting cohesion should be adapted to age, culture and gender for optimal results [6].

\section{Epidemiological Aspects: Infectious diseases and Outbreaks}

Travelling with a team of top athletes around the world as a team physician is a great pleasure and honor, but also a massive responsibility. No matter how immaculate the preparations are, one will always run into surprises and unforeseen events. As a team physician, however, one is confronted with some challenges almost with certainty. Regardless whether in Moscow, Stockholm, Buffalo or Prerov, an outbreak of some sort always hits. Clearly COVID-19 is exceptionally disruptive of monstrous proportions, but other pathogens can also cause havoc and have an impact of performance and the team as a whole, as a variety of infectious diseases can be transmitted during competitive sports and particularly team sports. In fact, up to 50\% all physicians and healthcare consultations visits in high-school and college sports are due to infectious diseases [11].

The most common pathogens include predominantly viruses but also a variety of fungi and gram-positive and gram-negative bacteria and depending on the team sport they are transmitted predominantly through contact (collision sports), air and droplets, water, food, blood and soil.

During the flu season, for instance, an airborne cold or a flu is unfortunately almost unavoidable and flu shots in the Autumn are encouraged. But also gastrointestinal pathogens transmitted through contaminated water can be complete game-changers and ruin games. Bottled water and hygiene measures in the locker rooms and restaurants alike are therefore of essence in avoiding gastroenteritis. 
Arguably, some difference in habits, hygiene measures and adherence between genders that influence outbreak patterns may exist. Behavioral factors and habits include cough hygiene, social customs, healthseeking behavior, and adherence to guidelines [12]. By sharing nail clippers, razers and other toiletries, towels or clothing in the locker-room, for instance, the skin-to-skin transmission of fungal infections such as ring-worm, viral Herpes Simplex or bacterial staphylococcal skin disease can be facilitated. (Table 1) Yet also other factors influence susceptibility to viruses and bacteria. For one, relative energy deficiency in sport (RED-S), which is the result of insufficient caloric intake and/or excessive energy expenditure, has an impact on immunity in addition to bone health, metabolism and protein synthesis, menstrual function, cardiovascular disorders, psychological health and finally performance [7]. Athletes suffering from RED-S are therefore more vulnerable to pathogens of all sorts as they have a weakened immune system. Finally, the iron metabolism can play a role particularly in female athletes with high iron loss due to heavy menstrual bleeding, and render them susceptibility to outbreaks.

\section{The Female Body: Typical Female Injuries, Metabolic Disorders and the}

\section{Menstrual Cycle}

While men rarely suffer from urinary tract infections, this is common in females - including female athletes - mainly due to anatomy. Hence, it is crucial to pay attention to preventive measures such as sufficient hydration, supplementing with cranberry extracts and to bring along enough apt antibiotics when travelling with the team.

The female cycle can have a significant impact on performance and well-being. Hence, female specific questions should already be raised in the pre-participation evaluation before each competitive season, and the training program and competition schedule should be planned according to the menstrual cycle or vice versa if possible. Clearly excessive bleeding can lead to iron deficiency. Hormonal contraception should also be selected individually to suit the type of sport, avoid excessive blood and iron loss, and to address any complaints the athlete may have [8]. Nevertheless, iron loss may still occur and might have to be replaced. Even though oral iron supplementation can lead to constipation and nausea, yet iron infusions are considered doping in many cases and must be evaluated carefully in accordance with anti-doping guidelines.

It is well known that stress fractures are more common in females than in men athletes. Clearly, relative energy deficiency in sport (RED-S) has an impact on bone health and stress fracture. Other common sports injuries in female athletes include anterior cruciate ligament (ACL) injuries and sport related concussions (SRC), while stress fractures and ACL injuries are at least partially influenced by female hormones $[9,10]$. Interestingly, the risk of rupture is significantly higher in the pre-ovulation phase of the menstrual cycle, which should be considered when designing the training plan.

\section{Summary}

Since the Title IX was established in the U.S. in 1972 ensuring that men and women have equitable participation opportunities as well as access to scholarships in sport programs, and since UNESCO recognized sports and physical activity as a human right in 1978, the world and the global sports communities have come a long way in pursuing gender equality in sports. 
The very motivational reasons for these developments are not purely ethical and moral, but also socioeconomic in nature. Supporting girls and women in sport leads to stronger women with critical thinking and leadership skills, stronger communities, and significantly contributes to overall economic growth and sustainable development. Particularly women in team sports seem to profit the most. Furthermore, promoting gender equality in sports does not contradict gender differences. While advocating equal rights and opportunities, it is in fact crucial to stimulate a discussion and to consider sex and gender differences while working with athletes and taking care of sports teams.

In summary, there are three levels that must be considered when addressing gender and sex differences in team sports, namely 1) the psychosocial level which includes the support of sports psychologists, the prevention of abuse, and team building for better performance and outcome, 2) the epidemiological level which takes into consideration vulnerability of teams to outbreaks and infectious pathogens due to differences in behavioral patterns and hygiene measures and the weakening of immune system because of iron loss during the menstrual cycle and RED-S, and 3) the individual level which addresses the female body, female hormones and metabolism, the menstrual cycle, and anatomic differences between males and females.

\section{Practical implications}

- Supporting girls and women in sport leads to stronger women with critical thinking and leadership skills, stronger communities, and significantly contributes to sustainable economic growth overall.

- Promoting gender equality in sports does not contradict gender differences.

- While advocating equal rights and opportunities, it is in fact crucial to stimulate a discussion and to consider sex and gender differences while working with athletes and taking care of sports teams.

- There are three levels that must be considered when addressing gender and sex differences in team sports, namely 1) the psychosocial level, 2) the epidemiological level, and 3) the individual level concerning the female body.

\section{Acknowledgments, conflict of interest and funding}

I thank the Swiss Ice Hockey Federation for a decade of great collaboration and Drs. Daniele Mona, JeanClaude Küttel, Lukas Weisskopf as well as Patrick Vavken for their support throughout the years. Conflict of interest: none declared.

\section{Corresponding author}

Anna Erat, $\mathrm{MD} / \mathrm{PhD}$

Witellikerstrasse 40, 8032 Zurich

Tel. +41 (0)443872050

E-Mail: anna.erat@hirslanden.ch

\section{References}

1. Ingram K. Why a female athlete should be your next leader. 23 September 2020. https://www.ey.com/en_gl/athlete-programs/why-female-athletes-should-be-your-next-leader (accessed 10 October 2020). 
2. Erat, A. Interview on Advancing Women in Sports - Challenges and Future Perspective in Sports Medicine! Sports \& Exercise Medicine Switzerland Journal, 2020;49(4).

3. Reardon CL, Hainline B, Aron CM, Baron D, Baum AL, Bindra A, et al. Mental health in elite athletes: International Olympic Committee consensus statement (2019). British Journal of Sports Medicine. 2019;53(11):667-99.

4. Mann BJ, Grana WA, Indelicato PA, O’Neill DF, George SZ. A survey of sports medicine physicians regarding psychological issues in patient-athletes. Am J Sports Med. 2007; Dec;35(12):2140-7.

5. Claussen MC, Gonzalez Hofmann C, Imboden C, Seifritz E, Hemmeter U. Swiss Society for Sports Psychiatry and Psychotherapy SSSPP. SSSPP Position paper: Mental health in competitive sport. Swiss Sports \& Exercise Medicine Switzerland Journal. 2020;68(3):23-6.

6. Martin LJ, Carron AV, Burke SM. Team building interventions in sport: A meta-analysis. Sport \& Exercise Psychology Review. 2009; 5,3-18.

7. Erat, A. Pre-participation Evaluation for Screening of Health Risks in Leisure and Young Competitive Athletes. Sports \& Exercise Medicine Switzerland Journal. 2019;67(3),6-11.

8. Matter Brügger S, Neuenschwander M. Zyklus und Leistungssport. Sports \& Exercise Medicine Switzerland Journal. 2020;49(4).

9. Mountjoy, M., Sundgot-Borgen, J. K., Burke, L. M., Ackerman, K. E., Blauwet, C., Constantini, N, Sherman RT. IOC consensus statement on relative energy deficiency in sport (RED-S): 2018 update. British Journal of Sports Medicine 2018.

10. Weidermann F. Behandlung von Sportverletzungen bei Frauen - Anders? Öfter? Länger? Sports \& Exercise Medicine Switzerland Journal. 45(4)2020.

11. McGrew CA. Acute infections. In: McKeag DB, Moeller JL, editors. ACSM’s Primary Care Sports Medicine. Philadelphia (PA); 2007, p. 251-60.

12. Frieden TR, Lee CT. Identifying and Interrupting Superspreading Events-Implications for Control of Severe Acute Respiratory Syndrome Coronavirus 2. Emerg Infect Dis. 2020;26(6):1059-1066.

13. Herzberg S, Motuapuaka M, Lambert W, Fu R, Brady J, Guise JM. The Effect of Menstrual Cycle and Contraceptives on ACL Injuries and Laxity: A Systematic Review and Meta-analysis. Orthopaedic Journal of Sports Medicine. 2017;jul21;5(7). 